\title{
DETERMINING PLANT WATER USE AND LANDSCAPE COEFFICIENTS OF SELECTED NURSERY AND LANDSCAPE PLANTS
}

\author{
A.A.Radwan ${ }^{1}, \quad$ M.N.El Awady ${ }^{2}$, M.M. Hegazy ${ }^{2}$ \\ and S.A. Mohamed ${ }^{3}$
}

ABSTRACT

This study, water use, species factor, and the overall growth of ten landscape plants grown in both 1.6 liter containers (commercial nursery practice) (simulation of landscape conditions) were determined and compared. Water use per plant and species factor were influenced by species. However, this means that the water use of container-grown plants may be used to predict or estimate the water use of the same species that are grown in a landscape situation. Water use per plant, landscape coefficient and overall growth differed by species. Of the ten species tested, shrubs(Hibiscus Rosa- sinensis, Acalypha Godseffiana, Lantana Camara Adhatode Vasica ,Phyllanthus, Dodonaea, , Acalypha Margenata) ground cover( Gazania,) and trees(Ficus Nitida, Ficus Bengamena), Water use per plant was highest and the same in Hibiscus Rosa- sinensis, Lantana Camara, and Acalypha Margenata (0.21L/day), while Dodonaea had the lowest water use(0.16L/day) for shrubs. Likewise, the trees water use was highest in Ficus Bengamena (0.36L/day).

\section{INTRODUCTION}

7 he increasing competition among agriculture, industry and municipal water users in arid and semi-arid regions has brought

L increased attention to water conservation and the improvement of irrigation efficiency. Since landscape and ornamental plants irrigation accounts for 40 to $60 \%$ of total household water consumption conserving and reducing the amount of water used for landscape and ornamental plants irrigation is critically important. Irrigation efficiency is improved by grouping plants with similar water requirements

1- Grand. Student; 2- Prof. Emt. of Ag. Eng., Ain-Shams Univ.; 3- Prof. Emt. of Ag. Horticulture, Ain-Shams Univ. 
and by scheduling irrigation based on specific plant needs. However, limited information exists on actual water requirements of landscape plants. Instead of the crop coefficient ( $\mathrm{k}$ ) for field agriculture, a landscape coefficient $\mathrm{K}_{\mathrm{L}}$ is suggested by the irrigation association (I A) and Awady et al., 2003 that consists of

$$
\mathrm{K}_{\mathrm{L}}=\mathrm{K}_{\mathrm{s}} \times \mathrm{K}_{\mathrm{mc}} \times \mathrm{K}_{\mathrm{d}},
$$

Where: $\mathrm{K}_{\mathrm{s}}$ is a factor for the turfgrass species and cultivar-it would be best for this factor to be determined under dry-down conditions from well-watered to moderate moisture stress.

$\mathrm{K}_{\mathrm{mc}}=$ microclimate influence.

$\mathrm{K}_{\mathrm{d}}=$ plant density.

WUCOLS(2000) and Awady et al.( 2003) used two formulas to estimate water needs for landscape plantings:

- the landscape evapotranspiration formula and,

- the landscape coefficient formula.

Water needs of landscape plantings can be estimated using the landscape evapotranspiration formula:

$$
\mathrm{ET}_{\mathrm{L}}=\mathrm{K}_{\mathrm{L}} \times \mathrm{ET}_{\mathrm{o}}
$$

Landscape Evapotranspiration =Landscape Coefficient $\mathrm{x}$ Reference Evapotranspiration

This formula (called the $\mathrm{ET}_{\mathrm{L}}$ formula) states that water needs of a landscape planting (landscape evapotranspiration, $\mathrm{ET}_{\mathrm{L}}$ ) is calculated by multiplying the landscape coefficient (KL) and the reference evapotranspiration (ETo).

As mentioned above, the ETL formula is basically the same as the ETc formula except that a landscape coefficient $\left(\mathrm{K}_{\mathrm{L}}\right)$ has been substituted for the crop coefficient $\left(\mathrm{K}_{\mathrm{c}}\right)$. This change is necessary because of important differences which exist between crop or turfgrass systems and landscape plantings.

Soil water availability plays a major role in controlling the rate of water loss from plants (ET rate). Many plants will lose water at a maximum rate as long as it is available. For example, some desert species have been found to maintain ET rates equivalent to temperate zone species when 
water is available. When soil moisture levels decrease, however, ET rates in desert species decline rapidly.

In landscape management, it is not the objective to supply all the water needed to maintain maximum ET rates. Rather, it is the intent to supply only a sufficient amount of water to maintain health, appearance and reasonable growth. Maximum ET rates are not required to do this. The $\mathrm{ET}_{\mathrm{L}}$ formula calculates the amount of water needed for health, appearance and growth, not the maximum amount that can be lost via evapotranspiration.ET Rates and Plant Water Needs.

This formula (called the $\mathrm{K}_{\mathrm{L}}$ formula) states that the landscape coefficient is the product of a species factor multiplied by a density factor and a microclimate factor. By assigning numeric values to each factor, a value for $\mathrm{K}_{\mathrm{L}}$ can be determined. The landscape coefficient is then used in the $\mathrm{ET}_{\mathrm{L}}$ formula, just as the crop coefficient is used in the $\mathrm{ET}_{\mathrm{c}}$ formula.

Begeman (1999) stated that location of a plant in a landscape affects its ET rate because of differences in available energy for evaporation. The following lists show locations that increase and decrease plant ET.

Increases available energy:

- South or west exposures (in the northern hemisphere)

- Reflected sunlight from surfaces

— Non-vegetative surroundings parking lots, streets

- Proximity to desert

- Exposure to dry hot winds or wind channeling

Decreases available energy:

— North or east exposures

- Shade by building

— Shade by other plants

- Sheltered from the wind.

- Locations in the center of large irrigated or wet areas.

Irrigation scheduling is defined as the process of determining when to irrigate and how much to apply. The goal of irrigation scheduling is to control the water status of the crop to achieve a targeted level of plant performance. The performance level can vary from optimizing irrigation input, to maximizing water use efficiency, to maximizing plant growth. 
Since the commercial value of woody landscape plants is generally based on size and aesthetics, most growers are focused on maximizing plant growth. Irrigation scheduling has received considerable attention in field crop production. However, no one has examined the impact of irrigation scheduling, i.e. time of irrigation application in regards to containergrown nursery crops. ( Warren and Bilderback, 2000).

\section{MATERIALS AND METHODS}

The following potential ornamental plants will be selected for this study. This selection is based on their planting popularity in Egypt landscapes. The ornamental plants are: Hibiscus Rosa- sinensis, Acalypha Godseffiana, Lantana Camara Adhatode Vasica, Phyllanthus, Dodonaea,, Acalypha Margenata, Gazania, Ficus Nitida, Ficus Bengamena.

Liners of the above plant species will be obtained in early spring from local nurseries and will be potted in 1.6, 2.6 liter containers filled with a common nursery growing medium. The containers will be placed in a fenced, outdoor field plot in completely randomized blocks with 6 replications. Plants will be fertilized with a controlled-release fertilizer.

All plants will be irrigated thoroughly, allowed to drain completely, and weighed. After 24 hours, the plants will be weighed again. The difference between the beginning and ending weights is the amount of water being used over the 24-hour period, in cubic centimeters or milliliter ( $\mathrm{ml}$ ).

ET landscape $(\mathrm{cm})=$ Volume of water use $(\mathrm{cm} 3) /$ container surface area (cm2)

landscape coefficient will be calculated as the following:

$$
\mathrm{K}_{\mathrm{L}}=\mathrm{ET}_{\mathrm{L}} / \mathrm{PET}
$$

Potential ET (PET) will be obtained from local weather stations. Since selected plant species may have different water use and tolerance to drought, the irrigation intervals will be adjusted properly so that every species will be re-irrigated before water stress sign exhibits. Therefore, the minimum water use of these plants will be the daily water use just before the stress sign exhibits.

This landscape is shown in Fig (1). The $\mathrm{a}$ and $\mathrm{b}$ dimensions are 9 and 14 $\mathrm{m}$, respectively. Reference $\mathrm{ET}_{0}$ is $7.5 \mathrm{~mm}$ on July from weather station (Central Laboratory for Agricultural Climate). 
The landscape is in direct sunlight. There are no plants under the trees. All plants are classified as a high water use plants $(\mathrm{H})$. Therefore, the species coefficient is 0.96 . the microclimate coefficient is 1.0 , because there is no shade. This is a tiered landscape with shrubs, turf, and trees so estimate the density coefficient was estimated as 1.2. Equation to calculate water requirement is as follows:

$$
\mathrm{W} \mathrm{R}=\mathrm{ET}_{0} * \mathrm{~K}_{\mathrm{L}} * \mathrm{~A}
$$

Where:

$\mathrm{W} \mathrm{R}=$ water requirement, liters per day for the area " $\mathrm{A}$ ",

$\mathrm{ET}_{0}=$ reference $\mathrm{ET}, \mathrm{mm} /$ day,

$\mathrm{A}=$ landscape area, $\mathrm{m}^{2}$,

$\mathrm{K}_{\mathrm{L}}=$ landscape coefficient, fraction.

W R $=7.5 *(0.96 * 1.0 * 1.2) * 9 * 14=1086.7 \mathrm{~L} / \mathrm{d}$, or

$\mathrm{W} \mathrm{R}=1.086 \mathrm{~m}^{3} / \mathrm{d}$

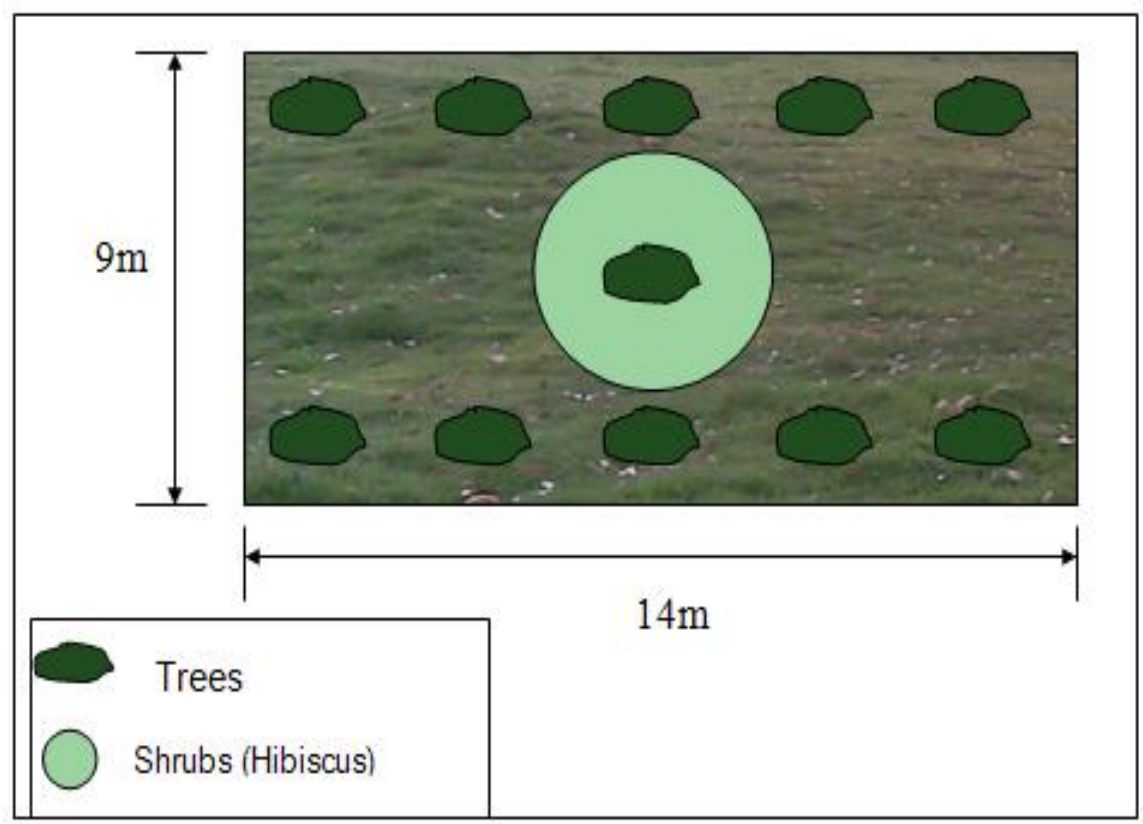

rig. I. Lanascape area witn trees, snruos, and turi grass.

\section{RESULTS AND DISSUCION}

Water use and species factor of (Hibiscus Rosa- sinensis, Acalypha Godseffiana, Lantana Camara, Adhatode Vasica, Phyllanthus, Dodonaea, Acalypha Margenata and Gazania) grown in containers over the five months. 


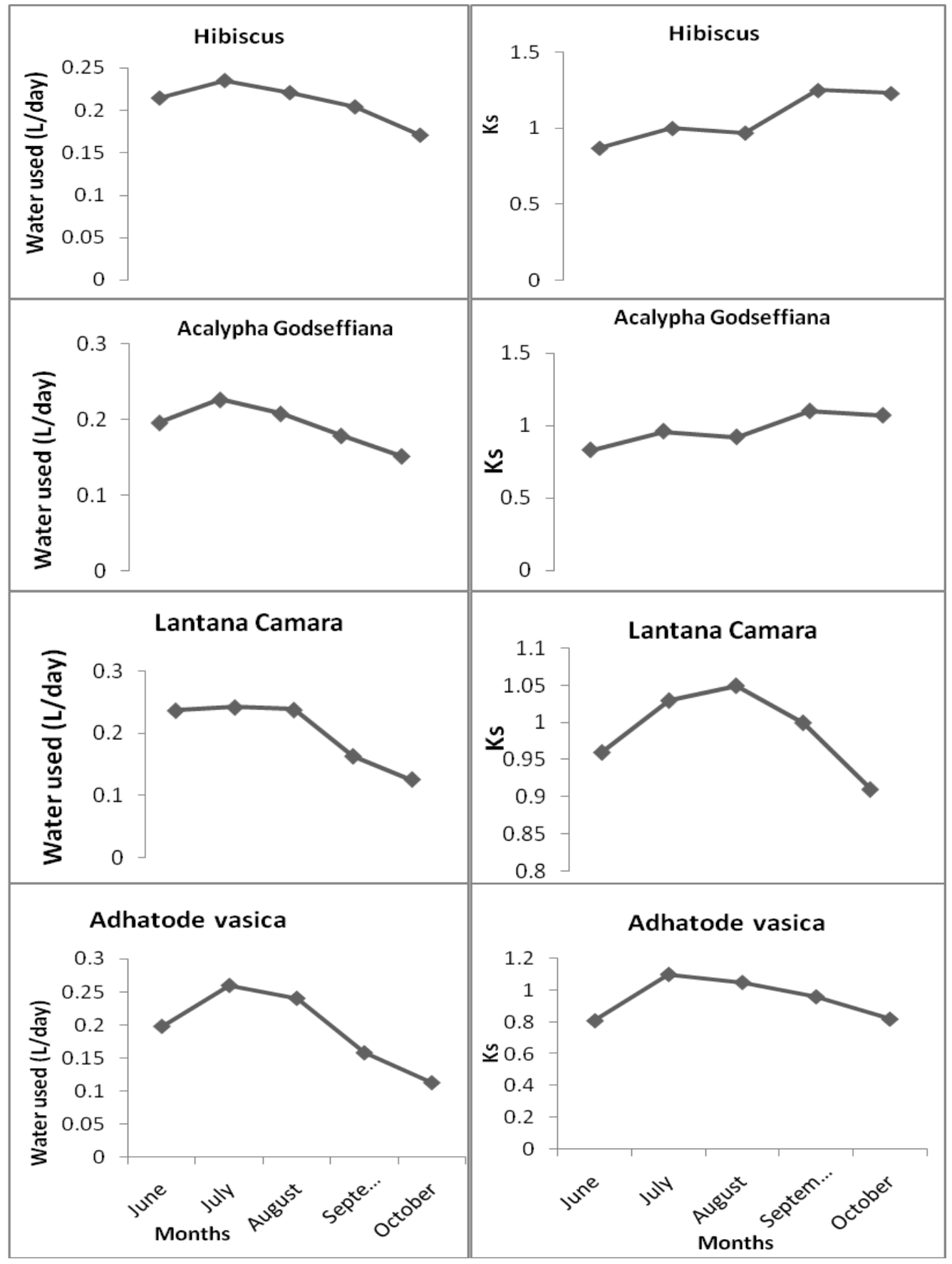

Fig. 2. Water use (L/day) and species factor $\left(\mathrm{K}_{\mathrm{s}}\right)$ of Hibiscus Rosasinensis, Acalypha Godseffiana, Lantana Camara and Adhatode Vasica. 
IRRIGATION AND DRAINAGE

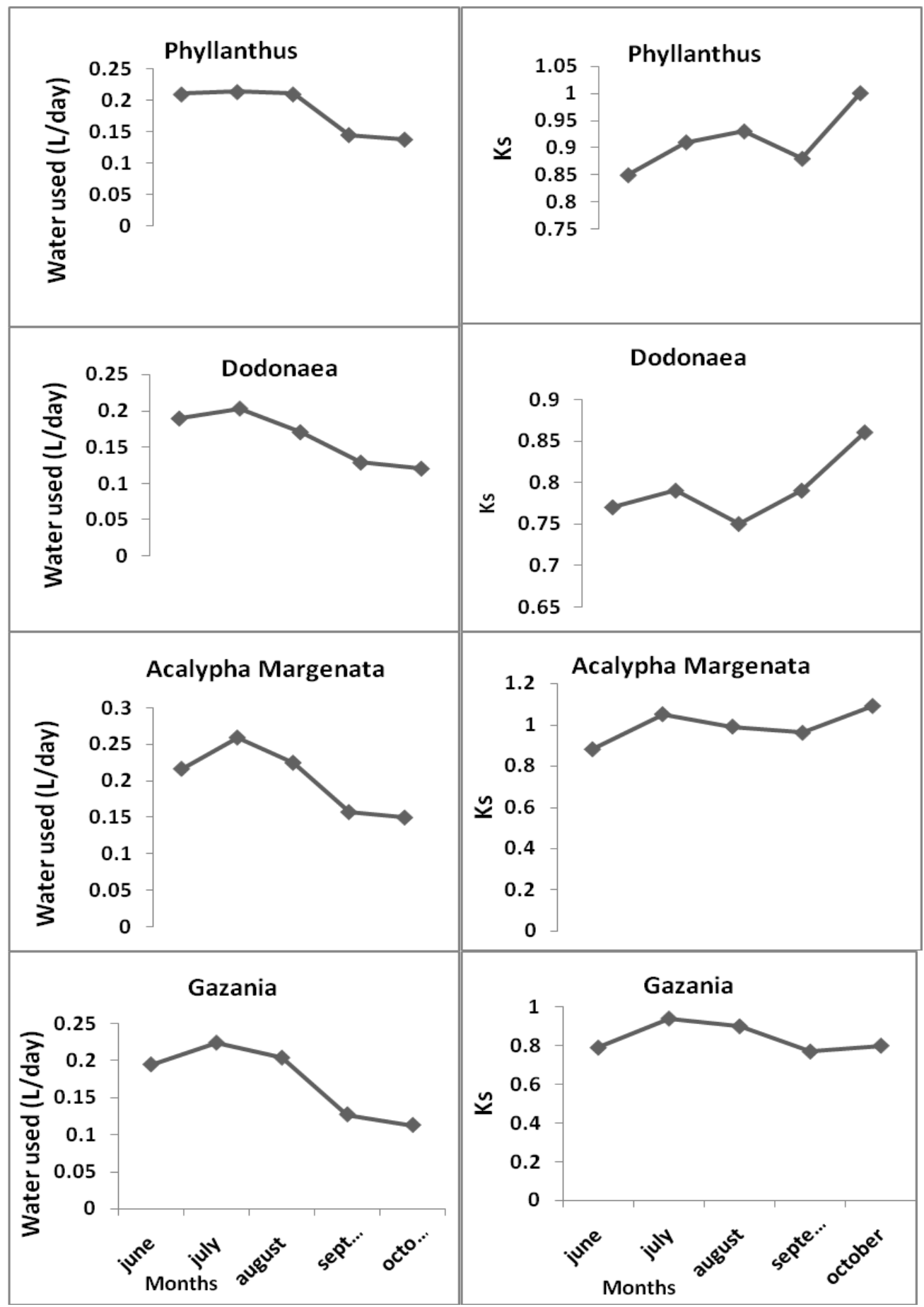

Fig. 3. Water use (L/day) and species factor $\left(\mathrm{K}_{\mathrm{s}}\right)$ of Phyllanthus, Dodonaea, Acalypha Margenata and Gazania. 
Water use per plant was highest and the same in Hibiscus Rosa- sinensis, Lantana Camara, and Acalypha Margenata (0.21L/day), while Dodonaea had the lowest water use(0.16L/day) for shrubs Fig.2 and Fig.3. The average species factor $\left(\mathrm{K}_{\mathrm{s}}\right)$ over the five months of Hibiscus Rosasinensis (1.04), was highest in other species, while Dodonaea had the same lowest $\mathrm{K}_{\mathrm{s}}(0.8)$ for shrubs. Acalypha Godseffiana, Lantana Camara, Adhatode Vasica, Phyllanthus, Acalypha Margenata (0.97, 0.99, 0.94, 0.91 and 0.99) resp.Fig.2 and Fig.3.

\section{CONCLUSIONS}

In summary, water use and landscape coefficient differed by species, growth, and months or days. Therefore, water use of landscape plants can be accurately estimated from container-grown plants provided that growth index and leaf area can be quantified. When applying this information to landscape situation, planting densities as well as growth rate need to be considered.

- Actual water use of plants will help the nursery industry, landscape professionals and homeowners to increase irrigation efficiency by scheduling irrigation timing and amount more accurately. Thus, irrigation water costs will be reduced and water will be conserved. In addition, runoff and groundwater pollution will be minimized.

- By grouping plants according to their relative drought tolerance and water use, landscape irrigation schedule and efficiency will be improved and water will be conserved.

\section{REFERENCES}

Awady, M. N. Vis , E. G., Kumar R. and Mitra S. 2003. Distribution uniformity from pop-up sprinklers and landscape water-saving. Misr J Ag. Eng. 20(4) :181-194.

Begeman, J.1999. Arizona Master Gardener Manual (Irrigation). Cooperative Extension Coll. Ag. Arizona

I A. 2005. Irrigation Association, Landscape Irrigation Scheduling and Water Management. pg22.

WUCOLS. 2000. A guide to estimating irrigation water of Landscape plantings in California, The landscape coefficient method and WUCOLS III. Cal Coop Ext, Cal Dept. of Water Resource, Bulletins and Reports.pp152. 


\section{الملخص العربي}

\section{تحديد الاحتياجات المائية ومعامل البستان لبعض نباتات الزينة}

أمل ابو المجد* أ.د.محمد نبيل العوضى ** أ.د. محمود حجازى**|.د.سهير السيد****

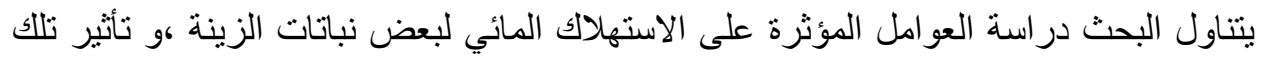

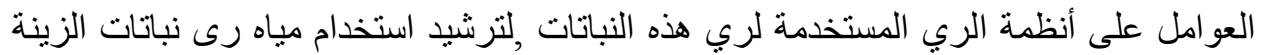

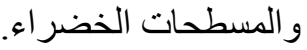

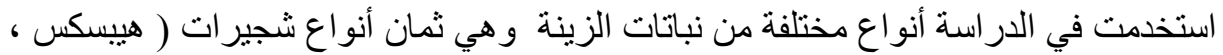

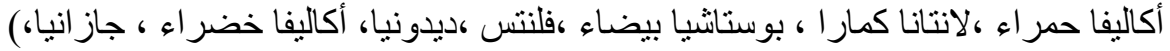

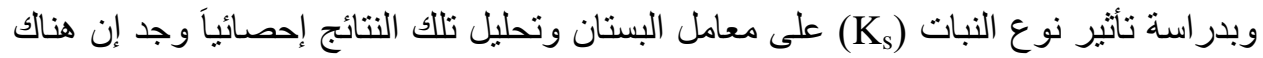

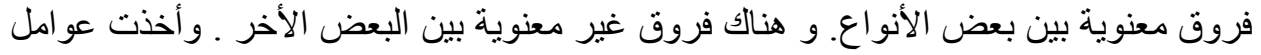

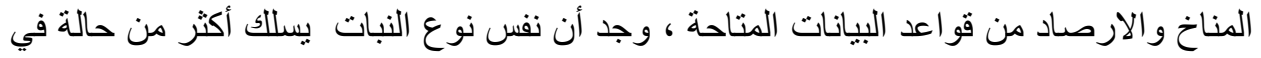

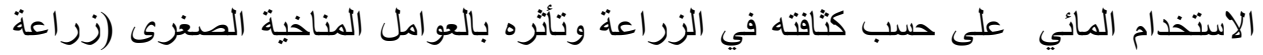

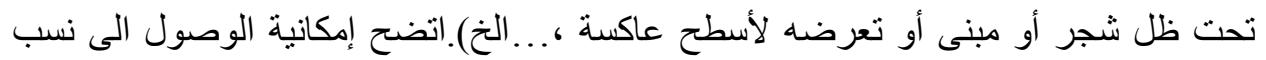

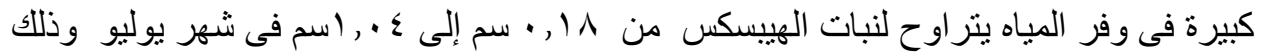
نتيجة التدقيق فى حسابات معاملات بساتين الزينة الاقرب للظروف النيات النيات السائدة.

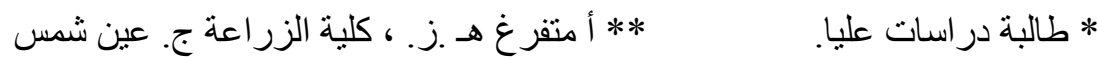

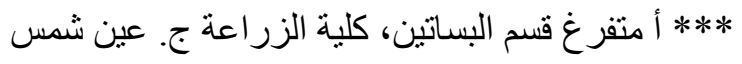

